Original article

\title{
Application of fuzzy inference system for determining weathering degree of some monument stones in Iran
}

\author{
${\text { Mojtaba Heidari }{ }^{\mathrm{a}, *} \text {, Carlos Chastre }}^{\mathrm{b}}$, Mehdi Torabi-Kaveh ${ }^{\mathrm{a}}$, Marco Ludovico-Marques ${ }^{\mathrm{c}}$, \\ Hassan Mohseni ${ }^{\mathrm{a}}$ \\ a Department of Geology, Faculty of Sciences, Bu-Ali Sina University, Mahdieh Ave., 65175-38695 Hamedan, Iran \\ b CEris, ICIST, Department of Civil Engineering, Faculdade de Ciencias e Tecnologia, Universidade NOVA de Lisboa, Caparica, Partugal \\ ' GCC, Barreiro School of Technology, Polytechnic Institute of Setúbal, Setúbal, Portugal
}

\section{A R T I C L E I N F O}

Article history:

Received 26 July 2016

Accepted 23 December 2016

Available online 25 January 2017

Keywords:

Monument stones

Weathering degree

Fuzzy inference system

\section{A B S T R A C T}

This paper presents a comparative evaluation of efficiencies of different accelerated ageing tests (freezethaw, thermal shock, salt crystallization, dissolution and wetting-drying) and fuzzy inference system in predicting weathering degrees of some monument stones from three historical sites (Anahita Temple, Anobanini reliefs and Eshkaft-e Salman reliefs, Iran). The combined effects of natural weathering processes (heating and cooling, wetting and drying, and freezing and thawing) and climatic information were used for assessing the natural weathering degrees. Finally, the natural weathering degrees were multiplied by time effect coefficients to obtain more realistic natural weathering degrees of the monuments. The predicted natural weathering degrees for Anahita Temple, Anobanini reliefs and Eshkaft-e Salman reliefs are $56 \%, 61 \%$, and $47 \%$, respectively. These predicted values reasonably support the weathering degrees defined by progressive decay indices (calculated equal to 2.77, 3.42 and 2.66 for Anahita Temple, Anobanini reliefs and Eshkaft-e Salman reliefs, respectively), which means the fuzzy model potentially could accurately predict the weathering of stones.

o 2017 Elsevier Masson SAS, All rights reserved. 